Japan. J. Trop. Med., Vol. 10, 186-187, 1969

\title{
STUDY OF JAPANESE ENCEPHALITIS VIRUS IN ANIMALS OF KOREA
}

\author{
Ho WANG LEE \\ Department of Microbiology, College of Medicine, Seoul \\ National University Seoul, Korea
}

There are only a few reports on natural history of encephalitis in Korea, but the ecology of encephalitis in Japan and that in Korea are presumed fundamentally similar because of their geographical location.

100 per cent of large demestic animal such as horse, cow and pig have neutralizing antibodies but it couldn't be detected in chicken though we tried in only small numbers.

The animals used in this experiment were too old to identify the history of the virus infection, it can be easily proved that they were bitten by infected mosquitoes.

Table 1. Occurrence of Hemagglutination-Inhibition Antibodies against Japanese Encephalitis Virus among Domestic Animals and Chickens

\begin{tabular}{lcc} 
& No. tested & No. positive* (\% positive) \\
\hline Horse & 54 & $47(87 \%)$ \\
Cattle & 92 & $82(89 \%)$ \\
Hog & 37 & $33(90 \%)$ \\
Dog & 48 & $8(17 \%)$ \\
Chicken & 136 & 1 \\
\hline
\end{tabular}

* Positive $=$ Inbibition of hemagglutination by a dilution of serum greater than or equal to, $1: 10$.

Table 2. Incidence of Neutralizing Antibodies for Japanese Encephalitis Virus Among Domestic Animals in Korea

\begin{tabular}{|c|c|c|c|c|c|c|}
\hline \multicolumn{7}{|c|}{ Domestic Aninal } \\
\hline \multirow{2}{*}{ Species } & \multicolumn{2}{|c|}{ Age (years) } & \multirow{2}{*}{$\begin{array}{l}\text { Summers } \\
\text { in area }\end{array}$} & \multirow{2}{*}{$\begin{array}{l}\text { No. } \\
\text { tested }\end{array}$} & \multirow{2}{*}{\multicolumn{2}{|c|}{$\begin{array}{l}\text { Per cent } \\
\text { positive }\end{array}$}} \\
\hline & Range & Mean & & & & \\
\hline Horses & $\begin{array}{l}7-12 \\
6-8\end{array}$ & $\begin{array}{l}9 \\
7\end{array}$ & $\begin{array}{l}1 \\
2\end{array}$ & $\begin{array}{l}4 \\
5\end{array}$ & $\left.\begin{array}{l}100 \\
100\end{array}\right\}$ & 100 \\
\hline Cows & $\frac{6-9}{6}$ & $\begin{array}{l}7 \\
6\end{array}$ & $\begin{array}{l}1 \\
2\end{array}$ & $\begin{array}{r}16 \\
1\end{array}$ & $\left.\begin{array}{r}94 \\
100\end{array}\right\}$ & 94 \\
\hline Pigs & $\begin{array}{l}1-2 \\
2-3\end{array}$ & $\begin{array}{l}2 \\
2\end{array}$ & 2 or $\stackrel{1}{\text { more }}$ & $\begin{array}{l}5 \\
5\end{array}$ & $\left.\begin{array}{l}100 \\
100\end{array}\right\}$ & 100 \\
\hline Chickens & $0.8-2$ & 1 & 1 & 12 & 0 & \\
\hline
\end{tabular}


HI antibody to the virus was proven in $87 \%$ of horse, in $89 \%$ of cattle and in $90 \%$ of pigs, The average age of horse and cattle was from 4 years to 7 years, and that of pigs varied from 6 months to 14 months.

There were reports in Korea since 1952 that the virus was isolated several times from naturally abortive pigs. When we surveyed on the multi-occurant region of encephalitis, we usually found that pigs were feeded in whole area of the village. It means the role of pig is amplifier in Korea as in Japan.

\title{
STUDIES ON JAPANESE ENCEPHALITS BY SURVEILLANCE CARDS
}

\author{
TADAhITO EZAKI, M. D.
}

Tokyo Municipal Fuchu Hospital, Japan

The author reviewed the epidemiological and clinical characteristics of Japanese encephalitis in Japan, based on statistical data acquired by card surveillance program established in nation-wide scale by Public Health Bureau of the Japanese Ministry of Health and Welfare since 1965.

Analysis of individual cards showed that, of the 1,344 cases (706 deaths) reported in 1965, 696 had been virologically diagnosed and 148 who died in early stage of their illness were regarded clinically to be Japanese encephalitis (Table 1).

Among 3,276 valid cards collected in 1966, 2,017 were made diagnosis of Japanese encephalitis by positive virus isolation or rising titers of $\mathrm{CF}$, HI or FA, and in autopsy or clinical aspects to the early death cases (Table 2).

As to the prognosis of the disease, of 811 cases tested in 1965, $48.9 \%$ were completely healed without any sequela and $19.2 \%$ were incomplete healing with various kinds of sequelae, and fatality rate was $31.8 \%$, whereas of the 1,995

Table 1. Result from Surveillance Cards of Each Reported Case in Seven Districts of Japan in 1965

\begin{tabular}{|c|c|c|c|c|c|c|c|c|}
\hline \multirow{2}{*}{ District } & \multicolumn{2}{|c|}{ Reported cases } & \multirow{2}{*}{$\begin{array}{l}\text { Valid } \\
\text { cards }\end{array}$} & \multirow{2}{*}{$\begin{array}{l}\text { Confirmed } \\
\text { cases }\end{array}$} & \multirow{2}{*}{$\begin{array}{l}\text { Suspected* } \\
\text { death }\end{array}$} & \multirow{2}{*}{$\begin{array}{l}\text { Equivocal } \\
\text { cases }\end{array}$} & \multirow{2}{*}{$\begin{array}{l}\text { Excluded } \\
\text { cases }\end{array}$} & \multirow{2}{*}{$\begin{array}{l}\text { Unknown } \\
\text { cases }\end{array}$} \\
\hline & Cases & Death & & & & & & \\
\hline Kyushu & 456 & 195 & 498 & 230 & 48 & 20 & 24 & 176 \\
\hline Shikoku & 68 & 56 & 108 & 39 & 11 & 5 & 2 & 51 \\
\hline Chugogu & 172 & 98 & 242 & 87 & 32 & 13 & 12 & 98 \\
\hline Kinki & 386 & 239 & 382 & 199 & 36 & 21 & 16 & 110 \\
\hline Chubu & 129 & 52 & 150 & 63 & 15 & 3 & 13 & 56 \\
\hline Kanto & 127 & 59 & 190 & 74 & 4 & 8 & 39 & 65 \\
\hline Tohoku & 6 & 7 & 22 & 4 & 2 & 0 & 3 & 13 \\
\hline Total & 1344 & 706 & 1592 & 696 & 148 & 70 & 109 & 569 \\
\hline
\end{tabular}

* Death following the typical encephalitis symptoms but not laboratory-confirmed. 